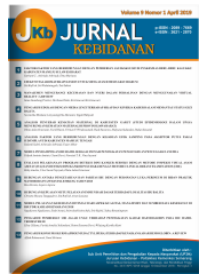

Volume 11 Nomor 1 (2021) 41-46

JURNAL KEBIDANAN

p-ISSN: 2089-7669 ; e-ISSN: 2621-2870

http://dx.doi.org/10.31983/jkb.v11i1.6462

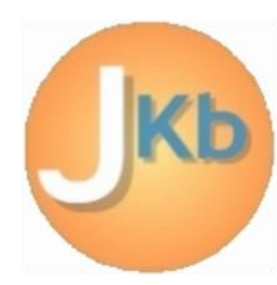

\title{
Application of "Stunting Prevention" Android-Based Applications to Mother Knowledege and Nutritional Status of Toddlers Ages 0-36 Months
}

\author{
Ervin Rufaindah ${ }^{1}$, Patemah $^{2}$ \\ ${ }^{1,2}$ Department of Midwifery, STIKES Widyagama Husada Malang, Indonesia \\ Jl. Taman Borobudur Indah No. 3A Malang \\ Corresponding author: Ervin Rufaindah \\ Email: ervinrufaindah@yahoo.com
}

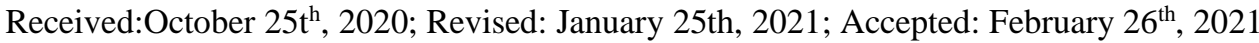

\begin{abstract}
Stunting is a growth disorder in children: the child's height is lower or shorter (stunted) than the standard age. A serious condition that occurs when a person does not get the right amount of nutritional intake for a long time (chronic). Contributes to 15-17 percent of all child deaths. The impact of stunting is underachieving in school and being less productive as adults. When the baby has passed the age of 9 months, it is possible for the mother not to bring her child back to the health service so that there is no monitoring of the child's development. This study utilizes an application "Stunting Prevention" which can be used by mothers to increase knowledge about how to prevent stunting. This study aims to determine the effect of the application of stunting prevention applications on maternal knowledge and nutritional status of children 0-36 months. The research design was a pre-experimental research design. This study uses the One Group Pretest-Posttest Design approach. The population in this study were mothers who have children aged 0-36 months in the Mojolangu Village, Malang City. The sampling technique used was purposive sampling. The results showed that there was an effect of using the application on maternal knowledge about stunting prevention with the results of wilcoxon analysis, namely $0,00(<0,05)$ and there was no effect of using the android application "Stunting Prevention" on the nutritional status of infants 0-36 months with a $\rho$ value of $0,317(0,05)$.
\end{abstract}

Keywords: Android application; Stunting Prevention

\section{Pendahuluan}

Stunting adalah Gangguan pertumbuhan pada anak : tinggi badan anak lebih rendahatau pendek (kerdil) dari standar usianya. Kondisi serius yang terjadi saat seseorang tidak mendapatkan asupan bergizi dalam jumlah yang tepat dalam waktu yang lama (kronik). Berkontribusi terhadap 15-17 persen dari seluruh kematian anak. Dampak sunting adalah kurang berprestasi di sekolah dan kurang produktif saat dewasa [1].

Kejadian stunting di Indonesia adalah 37, 2\%, sedangkan pada tahun 2019 di Kota Malang kejadian stunting adalah $17,8 \%$. Stunting
Disebabkan Oleh Faktor Multi Dimensi. Intervensi Paling Menentukan Pada 1000 Hari Pertama Kehidupan. Penyebab Lainnya:Praktek Pengasuhan Yang Tidak Baik, Kurangnya Akses Ke Makanan Yang Bergizi, Kurangnya Akses Ke Air Bersih Dan Sanitasi, Terbatasnya Layanan Kesehatan Termasuk Layanan ANC, Post Natal Dan Pembelajaran Dini Yang Berkualitas [2].

Stunting merupakan salah satu target Sustainable Development Goals (SDGs) yang termasuk pada tujuan pembangunan berkelanjutan ke-2 yaitu menghilangkan kelaparan dan segala bentuk malnutrisi pada tahun 2030 serta mencapai ketahanan pangan.Target yang ditetapkan adalah menurunkan angka stunting hingga $40 \%$ pada tahun 
2025. Balita setelah diukur panjang atau tinggi badan menurut umurnya,bila dibandingkan dengan standar baku WHO-MGRS(Multicentre Growth Reference Study) tahun 2005, nilaiz-scorenya kurang dari -2SD dikatagorikan pendek, dandikategorikan sangat pendek jika nilai zscorenya kurangdari -3SD [3].

Anak usia 0-12 bulan masuk dalam periode emasatau masa ketika otak anak sedang mengalami perkembangan yang pesat. Untuk Itu Orang Tua Harus Memperhatikan Asupan Kecukupan Gizi Anak melalui Inisiasi Menyusu Dini (IMD) segera setelah bayi lahir, Pemberian ASI eksklusif 0-6 bulan, MP-ASI (Makanan Pendamping Asi) makanan berkualitas dari bahan lokal mulai dari usia 6 bulan, lanjutkan ASI hingga 2 tahun/lebih [4].

Upaya yang sudah dilakukan pemerintah adalah pemberian suplementasi gizi makro dan mikro (Pemberian makanan tambahan, tablet tambah darah, vitamin A, taburia), promosi ASI Eksklusif, MP Asi, Kampanye gizi seimbang, kelas ibu hamil, pemberian obat cacing, penanganan kekurangan gizi, dan program jaminan kesehatan nasional. Upaya untuk mengurangi jumlah stunting adalah menjaga gizi anak sejak dalam kandungan sampai usia dua tahun. Peran seorang ibu dan kader posyandu sangat diperlukan dalam hal ini. Seorang ibu harus memiliki pengetahuan yang baik tentang gizi selama kehamilan sampai anaknya berumur dua tahun.Salahsatu pemantauan status gizibalita bisa melalui posyandu balita dan kader sebagai pendamping dan pendukung orang tua dalam pemantauan $\mathrm{BB}$ (beratbadan) dan $\mathrm{PB} / \mathrm{TB}$ (Panjang/Tinggi Badan)balitanya [5].

Tenaga kesehatan harus terlibat dalam memberikan promosi nutrisi selama kehamilan, memberikan dampak terhadappengetahuan ibu dan kesehatan ibu dan anak. Sehingga diperlukanupaya pencegahan terjadinya stunting pada balita baiksecara langsung (intervensi gizi spesifik) maupunsecara tidak langsung yang melibatkan lintas sektor danmasyarakat dalam penyediaan pangan, air bersih dansanitasi, penangulangan kemiskinan, pendidikan, sosial dan sebagainya [6].

Saat bayi berusia $0-9$ bulan masih mendapatkanimuniasi dasar lengkap, sehingga memungkinkan ibu membawa bayinyake posyandu atau pelayanan kesehatan lainnya. Ketika bayi sudah melewati usia 9 bulan tidak menutup kemungkinanibu tidak membawa kembali anaknya kepelayanan kesehatan sehingga tidak dilakukan pemantauan tumbuh kembang anak [7].
Peranan ibu sangat bermanfaat bagi proses perkembangan danpertumbuhan anak secara keseluruhan sejak dalam kandungan. Beberapa faktor yang mempengaruhi kemampuan orang tua dalam pemenuhan gizi anak adalaah orangtua yangsibuk bekerja, kurang memiliki waktu, bahkan kurangnya pengetahuan tentanggizi anak [8].

Seiring mobilitas yang tinggi munculah berbagai perangkat mobile.Salah satu perangkat mobile yang paling pesatadalah handphone dan hampir setiap orangmemilikinya. Fungsi utama handphone adalahsebagai alat komunikasi, namun saat ini denganberbagai fitur di dalamnya seperti pengolahgambar, video dan pengolah dokumen dan lain sebagainya menambah fungsi handphone tersebut. Salah satu aspek teknologi handphone yang sedang berkembang adalah teknologimobile smartphone. Teknologi smartphone yangsedang menjadi tren saat ini adalah adanya sistem operasi berbasis android.Banyak kalanganpraktisi dan akademisi mengembangkan aplikasi berbasis android, sehingga di nilai dapat memberikan kemudahan, efisien dan keuntunganbagi penggunanya [8].

Pemanfaatan perkembangan teknologi sangat memungkinkan untuk dikembangkan sistem yang menggantikan peranseorang tenaga ahli dibidang kesehatan, melihatsemakin berkembangnya smartphone androidsaat ini memungkinkan untuk dijadikan media pendidikan kesehatan untuk mencegah stunting.Smartphoneselain digunakan sebagai alat komunikasi, android juga sudah menjadi sebuah kebutuhanbagi masyarakat modern, sehingga sudah sangatdikenal dikalangan masyarakat umum [8].

Berdasarkan penelitian sebelumnya, aplikasi android status gizi dapat meningkatkan pengetahuan ibu tentang pemantauan status gizi balita. Aplikasi android Stimulasi Tumbuh Kembang berpengaruh Terhadap Pengetahuan Ibu Dan Pertumbuhan Balita. Akan tetapi, belum ada penelitian mengenai pengaruh aplikasi android pencegahan stunting terhadap pengetahuan ibu dan status gizi balita.

Pada penelitian ini memanfaatkan sebuah aplikasi "Pencegahan Stunting" yang dapat digunakan ibu dalam peningkatan pengetahuan tentang cara mencegah stunting. Pada sistem ini berisi informasi tentang pencegahan stunting pada masa kehamilan, saat persalinan, memberikan ASI Eksklusif (pada bayi 0-6 bulan), MP ASI+ASI sampai bayi umur 2 tahun, Memberikan imunisasi, 
Pantau tumbuh kembang dengan rutin, Gaya hidup bersih dan sehat. Aplikasi ini dibuat oleh peneliti dan ahli teknologi, dengan isi materi yang sudah disesuaikan dengan jurnal. Dengan aplikasitersebut diharapkan ibu dapat mengakses informasi cara mencegah stunting sejak kehamilan sampai bayi berumur dua tahun. Informasi yang terdapat dalam aplikasi menggunakan bahasa yangmudah dipahami dan visualisasi yang menarik.

\section{Metode Penelitian}

Desain penelitian ini adalah desain penelitian pre-experimental design. Penelitian ini menggunakan pendekatan One Group PretestPosttest Design yaitu dengan cara memberikan pre test terlebih dahulu sebelum diberikan intervensi. Setelah diberikan intervensi (mengakses aplikasi android) selama 4 minggu, kemudian dilakukan post test. Populasi dalam penelitian ini adalah ibuibu yang mempunyai balita usia 0-36 bulan dan mempunyai serta dapat mengoperasionalkan hp android di wilayah Kelurahan Mojolangu Kota Malang. Teknik sampling yang digunakan adalah purposive sampling. Responden dikumpulkan dalam satu hari namun dilakukan secara empat gelombang dengan tetap menjalankan protokol kesehatan untuk mengakses aplikasi. Materi yang disajikan didapatkan dari jurnal. Dalam proses pembuatan aplikasi, tim peneliti bekerja sama dengan pakar informasi dan teknologi.

Setelah aplikasi selesai maka dilakukan uji Usability Test untuk menilai kualitas ketergunaan aplikasi. Pada sistem ini berisi informasi tentang pencegahan stunting pada masa kehamilan, saat persalinan, memberikan ASI Eksklusif (pada bayi 0-6 bulan), MP ASI+ASI sampai bayi umur 2 tahun, Memberikan imunisasi, Pantau tumbuh kembang dengan rutin, Gaya hidup bersih dan sehat. Kemudian dilakukan Uji Validitas menggunakan uji product moment dan Uji Reliabilitas menggunakan Uji Alfa Cronbach. Uji validitas dan reliabilitas dilakukan kepada 20 ibu balita 0-36 bulan yang memiliki karakteristik sama dengan responden. Penelitian ini sudah lolos uji etichal clearance. Alat untuk pengumpulan data pengetahuan ibu menggunakan kuisioner dalam bentuk google form sebanyak 50 soal multiple choice yang sudah disesuaikan dengan isi/materi dalam aplikasi, sedangkan status gizi didapatkan dari laporan ibu bayi balita dibuktikan dengan KMS (kartu menuju sehat). Analisis yang digunakan dalam penelitian ini adalah analisis perbedaan antara nilai pre dan post pada kelompok dengan menggunakan uji Wilcoxon.

\section{Hasil dan Pembahasan}

\section{Tabel 1.}

Penerapan Aplikasi Pencegahan Stunting Terhadap Pengetahuan Ibu Balita 0-36 bulan

\begin{tabular}{llccc}
\hline & & & \\
& & Pukup & Baik & Total \\
\hline PreTest & Kurang & $2(5,3 \%)$ & $3(7,9 \%)$ & $5(13,2 \%)$ \\
& Cukup & $1(2,6 \%)$ & $11(28,9 \%)$ & $12(31,5 \%)$ \\
& Baik & 0 & $21(55,3 \%)$ & $21(55,3 \%)$ \\
Total & & $3(7,9 \%)$ & $35(92,1 \%)$ & $38(100 \%)$ \\
\hline
\end{tabular}

Wilcoxon Signed Ranks Test $: \rho=0,00$

Tabel 2.

Penerapan Aplikasi Pencegahan Stunting Terhadap Status Gizi Balita 0-36 bulan

\begin{tabular}{|c|c|c|c|c|c|}
\hline \multirow{2}{*}{ gizi } & \multirow[t]{2}{*}{ Status } & \multicolumn{3}{|c|}{ PostTest } & \multirow[b]{2}{*}{ Total } \\
\hline & & Pendek & Normal & Tinggi & \\
\hline \multirow{3}{*}{ PreTest } & Pendek & $2(5,3 \%)$ & $0(0 \%)$ & 0 & $2(5,3 \%)$ \\
\hline & Normal & $0(0 \%)$ & $32(84,2 \%)$ & $1(2,6 \%)$ & $33(86,8 \%)$ \\
\hline & Tinggi & $0(0 \%)$ & 0 & $3(7,9 \%)$ & $3(7,9 \%)$ \\
\hline Total & & $2(5,3 \%)$ & $32(84,2 \%)$ & $4(10,5 \%)$ & $38(100 \%)$ \\
\hline
\end{tabular}

Wilcoxon Signed Ranks Test : $\rho=0,317$ 
Penelitian ini dilakukan pada 38 ibu balita usia 0-36 bulan yang memenuhi kriteria inklusi di Kelurahan Mojolangu Kota Malang. Berdasarkan Tabel 1. diperoleh data pengetahuan responden sebelum mendapat penerapan aplikasi pencegahan stunting paling banyak berpengetahuan baik yaitu 21 responden $(55,3 \%)$ dan setelah mendapatkan penerapan aplikasi pencegahan stunting paling banyak berpengetahuan baik yaitu 35 responden $(92,1 \%)$. Ada perbedaan pengetahuan sebelum memakai aplikasi dan sesudah memakai aplikasi dengan nilai $\rho$ didapatkan dari analisis wilcoxon yaitu $0,00(<0,05)$.

Perkembangan teknologi sekarang inisemakin marak dan berkembang pesat sehingga banyak membantu masyarakat untuk menikmati berbagai kemudahan yang telah dihasilkan oleh teknologi tersebut. Salah satu aspek teknologi mobile pada perangkat telepon pintar (smartphone). Teknologi smartphone yang sedang menjadi tren saat ini adalah adanya sistem operasi berbasis android, sehingga dinilai dapat memberikan banyak kemudahan dan keuntungan bagi penggunanya, dengan demikian smartphone android saat ini memungkinkan untuk dijadikan media sosialisasi pencegahan stunting dan status gizi [[8][12]].

Aplikasi pencegahan stunting merupakan aplikasi berbasis android yang berisi tentang pencegahan stunting pada masa kehamilan, saat persalinan, memberikan ASI Eksklusif (pada bayi 0-6 bulan), MP ASI+ASI sampai bayi umur 2 tahun, Memberikan imunisasi, Pantau tumbuh kembang dengan rutin, Gaya hidup bersih dan sehat. Aplikasi disajikan dengan gambar animasi yang menarik serta bahasa yang mudah dipahami. Kelebihan aplikasi ini dapat membantu meningkatkan pengetahuan Ibu dalam pencegahan stunting.

Rentang usia responden paling banyak adalah 21-35 tahun(68,4\%). Usia 21-35 tahun adalah usia produktif yang memiliki kemampuan untuk mempelajari, memahami dan mengingat informasiinformasi penting, salah satunya adalah informasi kesehatan tentang pencegahan stunting. Karena kemampuan memahami informasi baik, maka baik pula dalam menerapkan suatu ilmupengetahuan serta teknologi [2].

Tingkat pendidikan responden paling banyak $(60,5 \%)$ adalah tingkat menengah (SMA/SMK). Jenjang pendidikan mempengaruhi seseorang dalam menerima informasi dan pengetahuan. Pendidikan tinggi mengajarkan orang untuk berpikir lebih logis dan rasional, dapat melihat sebuah isu dari berbagai sisi sehingga dapat lebih melakukan analisis dan memecahkan suatu masalah. Selain itu, pendidikan tinggi memperbaiki keterampilan kognitif yang diperlukan untuk dapat terus belajar di luar sekolah [2].

Berdasarkan Tabel 2. Menunjukkan tidak ada perbedaan status gizi sebelum memakai aplikasi dan sesudah memakai aplikasi dengan nilai $\rho$ didapatkan dari analisis wilcoxon yaitu 0,317 $(>0,05)$. Hal ini menunjukkan bahwa aplikasi dalam smart phone tersebut belum mampu membantu merubah status gizi secara statistik. Status gizi adalah ekspresi dari keadaan keseimbangan dalam bentuk variabel tertentu, atau perwujudan dari nutriture dalam bentuk variabel tertentu. Berdasarkan Keputusan Menteri Kesehatan Republik Indonesia Nomor: 1995/MENKES/SK/XII/2010 menimbang bahwa, untuk menilai status gizi anak diperlukan standar antropometri yang mengacu pada Standar World Health Organization (WHO 2005). Sesuai dengan Riskesdas (2013), status gizi anak balita diukur berdasarkan umur, berat badan (BB) dan tinggi badan (TB). Penilaian status gizi balita dilakukan dengan mengkonversikan angka berat badan dan tinggi badan ke dalam nilai terstandar $\mathrm{z}$-skor menggunakan baku antropometri balita. Hasil dari perhitungan z-skor tersebut, dikonversikan menjadi kategori status gizi yaitu Sangat pendek $(<-3 \mathrm{SD})$, Pendek (-3 SD sampai dengan <-2 SD), Normal (2 SD sampai dengan $2 \mathrm{SD}$ ), Tinggi (>2 SD) [13].

Perubahan status gizi pre dan post test terjadi pada satu $(2,6 \%)$ responden yaitu status gizi normal menjadi tinggi. Hal tersebut dikarenakan tinggi badan anak ada pada ambang batas yang berdekatan, sedangkan anak yang lain tidak mengalami perubahan status gizi karena ambang batas yang terlalu luas dalam penelitian yang hanya dilakukan 4 minggu. Meskipun status gizi tidak berubah, Panjang Badan (PB) atau Tinggi Badan (TB) anak bertambah saat pengukuran pre dan post test selama 4 minggu ini.

Aplikasi android efektif dalam peningkatan layanan kesehatan karena mudah digunakan, penggunaan luas dalam memperoleh informasi, mudah dibawa kemanapun. Dengan adanya aplikasi android, akan meningkatkan peran keluarga dan dukungan sosial yang akan mempengaruhi proses tumbuh kembang balita [[14],[15]].

Penghasilan keluarga tiap bulan $(63,2 \%)$ $>$ Rp.2.895.502(>UMR = upah minimum regional). UMR yang dimaksud dalam penelitian ini adalah pendapatan keluarga dalam satu bulan. UMR Kota Malang Tahun 2020 adalah Rp.2.895.502. Menurut 
Bishwakarma, 2011 Status ekonomi secara tidak langsung dapat mempengaruhi status gizi anak. Sebagai contoh, keluarga dengan status ekonomi baik bisa mendapatkan pelayanan umum yang lebih baik juga, yaitu pendidikan, pelayanan kesehatan, aksesibilitas jalan, dan sebagainya. Melalui fasilitas-fasilitas tersebut keluarga dengan status ekonomi baik akan berdampak positif terhadap status gizi anak. Hal ini menunjukkan perbaikan kecil dalam status sosial ekonomi memiliki dampak penting kesehatan anak [2].

Ada $73,7 \%$ ibu-ibu memberikan ASI Eksklusif kepada anak. Menyusui secara eksklusif pada usia 0-6 bulan memiliki banyak manfaat karena usus bayi belum mampu mencerna makanan selain ASI. Selain itu pengeluaran sisa pembakaran makanan belum bisa dilakukandengan baik karena ginjal belum sempurna. Manfaat ASI Eksklusif sangatbanyak yaitu peningkatan kekebalan tubuh, pemenuhan kebutuhan gizi, meningkatkan jalinan atau ikatan batin antaraibu dan anak, murah, mudah, bersih dan higienis. Pemberian ASI yang kurang sesuai di Indonesia menyebabkan bayi menderita gizi kurang dan gizi buruk. Padahalkekurangan gizi pada bayi akan berdampakpada gangguan psikomotor, kognitif dan sosialserta secara klinis terjadi gangguan pertumbuhan. Dampak lainnya adalah derajat kesehatan dan gizi anak Indonesia masih memprihatinkan sehingga resiko stunting lebih besar [9].

Pemberian MP-ASI pada anak dilakukan pada usia $>6$ bulan sebanyak $68,4 \%$. Pertumbuhan dan perkembangan bayi membutuhkan gizi yang baik dan seimbang, dan kemampuan bayi berhubungan dengan alat pencernaannya, hanya mampu mencerna ASI dan ASI dapat memenuhi kebutuhan bayi selama berbulan-bulan pertama. Anak yang tidak mendapatkan ASI eksklusif berisiko lebih tinggi untuk kekurangan zat gizi yang diperlukan untuk proses pertumbuhan. Gangguan pertumbuhan akan mengakibatkan terjadinya stunting pada anak [10].

Paling banyak responden $(94,7 \%)$ sudah memberikan imunisasi dasar lengkap pada anaknya. Imunisasi memberikan efek kekebalan tubuh terhadapmanusia, dibutuhkan terutama pada usia dini yang merupakan usia rentan terkena penyakit. Dampakdari sering dan mudahnya terserang penyakit adalahgizi buruk. Gizi buruk erat kaitannya dengan stunting [11].

Paling banyak $(94,7 \%)$ anak dibawa ke posyandu untuk pemantauan tumbuh kembang setiap bulan. Orang tua perlu terus memantau tumbuh kembang anak mereka, terutama tinggi dan berat badan anak. Bawa anak secara berkala ke Posyandu maupun klinik khusus anak. Dengan begitu, akan lebih mudah bagi ibu untuk mengetahui gejala awal gangguan dan penanganannya [7].

Sumber air responden berasal dari sumur/pompa sebanyak 76,3\% dan 94,7\% memiliki WC dengan septitank. Anak-anak sangat rentan akan serangan penyakit, terutama jika lingkungan sekitar mereka kotor. Faktor ini pula yang secara tidak langsung meningkatkan peluang stunting. Diare adalah faktor ketiga yang menyebabkan gangguan kesehatan tersebut. Sementara salah satu pemicu diare datang dari paparan kotoran yang masuk ke dalam tubuh anak [6].

\section{Simpulan}

Ada perbedaan pengetahuan sebelum memakai aplikasi dan sesudah memakai aplikasi dengan nilai $\rho$ didapatkan dari analisis wilcoxon yaitu $0,00(<0,05)$ dan tidak ada perbedaan status gizi sebelum memakai aplikasi dan sesudah memakai aplikasi dengan nilai $\rho$ didapatkan dari analisis wilcoxon yaitu $0,317(>0,05)$. Diharapkan pada peneliti selanjutnya untuk melakukan penelitian lebih lama sehingga status gizi dapat berubah lebih baik untuk semua responden. Perubahan status gizi dalam penelitian ini hanya terjadi pada satu responden yaitu status gizi normal menjadi tinggi. Hal tersebut dikarenakan tinggi badan anak ada pada ambang batas yang berdekatan, sedangkan anak yang lain tidak mengalami perubahan status gizi karena ambang batas yang terlalu luas dan penelitian yang hanya dilakukan 4 minggu. Meskipun status gizi tidak berubah, Panjang Badan (PB) atau Tinggi Badan (TB) anak bertambah saat pengukuran pre dan post test selama 4 minggu ini.

\section{Ucapan Terimakasih}

Terima kasih kami ucapkan kepada Kelurahan Mojolangu, Bidan, Kader Serta Responden yang bersedia membantu dan mendukung dalam penelitian ini.

\section{Daftar Pustaka}

[1] S. Mawaddah, "Hubungan Pemberian ASI Eksklusif dengan Kejadian Stunting pada Balita Usia 24-36 Bulan," J. Berk. Kesehat., vol. 5, no. 2, pp. 60-66, 2019. 
[2] D. N. Sari and V. Medhyna, "Faktor - Faktor Yang Mempengaruhi Kejadian Stunting Pada Balita Di Puskesmas Biaro Kabupaten Agam Tahun 2018," Matern. Child Heal. Care J., vol. 1, no. 2, pp. 18-35, 2019.

[3] N. Y. Prihutama, F. A. Rahmadi, and G. Hardaningsih, "Pemberian Makanan Pendamping Asi Dini Sebagai Faktor Risiko Kejadian Stunting Pada Anak Usia 2-3 Tahun," J. Kedokt. Diponegoro, vol. 7, no. 2, pp. 1419 1430, 2018.

[4] E. Yuliawati, N. Sulung, and E. Hasnita, "Inisiasi Menyusu Dini, Keanekaragaman Makanan dan Jaminan Kesehatan Terhadap Kejadian Stunting," J. Hum. Care, vol. 4, no. 3, pp. 132-137, 2019.

[5] M. K. Hara, "Perilaku Asupan Nutrisi Balita Berhubungan Dengan Perubahan Status Gizi Dari Balita Kurang Gizi Yang Mendapat Program Pmt-P, Puskesmas Kawangu Sumba Timur," J. Info Kesehat., vol. 13, no. 2, 2014.

[6] A. K. Sinatrya and L. Muniroh, "Hubungan Faktor Water, Sanitation, and Hygiene ( WASH ) dengan Stunting di Wilayah Kerja Puskesmas Kotakulon , Kabupaten Bondowoso," IAGIKMI, pp. 164-170, 2019.

[7] M. N. Hairunis, H. Salimo, Y. Lanti, and R. Dewi, "Hubungan Status Gizi dan Stimulasi Tumbuh Kembang dengan Perkembangan Balita," vol. 20, no. 36, pp. 1-6, 2018.

[8] I. G. Pratiwi, D. A. Restanty, P. K. Mataram, and P. K. Malang, "Penerapan Aplikasi Berbasis Android 'Status Gizi Balita Terhadap Pengetahuan Ibu Dalam Pemantauan Status Gizi Anak Usia 12-24 Bulan,"” JKAKJ, vol. 2, no. 1, pp. 8-14, 2018.
[9] J. Pengan, S. Kawengian, D. V Rombot, F. Keshetana, M. Sam, and R. Manado, "Hubungan Antara Riwayat Pemberian Asi Eksklusif Dengan Kejadian Stunting Pada Anak Usia 12-36 Bulan Di Wilayah Kerja Puskesmas Luwuk Kecamatan Luwuk Selatan Kabupaten Banggai Sulawesi Tengah,” 2015.

[10] M. Nova and O. Afriyani, "Hubungan Berat Badan, Asi Eksklusif, Mp-Asi Dan Asupan Energi Dengan Stunting Pada Balita Usia 2459 Bulan Di Puskesmas Lubuk Buaya," vol. 5, no. 1, pp. 47-53, 2018.

[11] D. Swathma, H. Lestari, and R. Teguh, "Analisis Faktor Risiko BBLR, Panjang Badan Bayi Saat Lahir dan Riwayat Imunisasi Dasar Terhadap Kejadian Stunting pada Balita Usia 12-36 Bulan di Wilayah Kerja Puskesmas Kandai Kota Kendari Tahun 2016," pp. 1-10, 2016.

[12] M. Bakhar and I. D. Andari, "Pengaruh Penggunaan Aplikasi Stimulasi Tumbuh Kembang Terhadap Pengetahuan Ibu Dan Pertumbuhan Balita," J. SIKLUS, vol. 07, no. 02, pp. 328-333, 2018.

[13] C. D. Saripah, "Aplikasi Nusa ( Nutrition Status Assesment ) Untuk Penilaian Status Gizi Balita Berdasar Standar WHO 2005," 2015.

[14] W. I. Susanti and S. A. Nugraheni, "Pengembangan Sistem Informasi Pencatatan dan Pelaporan Status Gizi Balita Stunting di Kelurahan Gajahmungkur," J. Manaj. Kesehat. Indones., vol. 7, no. 1, pp. 67-74, 2019.

[15] S. Astuti, G. Megawati, and S. CMS, "Gerakan Pencegahan Stunting melalui pemberdayaan masyarakat di kecamatan jatinangor kabupaten sumedang," vol. 7, no. 3, pp. 185-188, 2018. 